$5+37-73$

DCT $6^{-}-1997^{\circ}$ ENGINEERING DATA TRANSMITTAL

2. To: (Receiving Organization) Hanford Tanks Initiative (HTI) Project

5. Proj./Prog./Dept./Div.:

HTI Project/LMHC

8. Originator Remarks:

Item 1 was performed by Sandia National Laboratories, Albuquerque, New Mexico, during Fiscal Year 1997 under funding provided by the Tanks Focus Area (EM-50).

11. Receiver Remarks: 11A. Design Baseline Document? [] Yes [X] No
3. From: (Originating Organization) Hanford Tanks Initiative (HTI) Project

6. Design Authority/ Design Agent/Cog, Engr.: D. L. Becker

\begin{tabular}{|c|} 
4. Related EDT No.: \\
None \\
7. Purchase Order No.: \\
N/A \\
$\begin{array}{c}\text { 9. Equip./Component No.: } \\
\text { N/A }\end{array}$ \\
$\begin{array}{c}\text { 10. System/8ldg-/Facility: } \\
\text { N/A }\end{array}$ \\
$\begin{array}{c}\text { N/A } \\
\text { 12. Major Assm. Dwg. No.: } \\
\text { N/A }\end{array}$ \\
\hline 13. Permit/Permit.Application No.: \\
\hline 14. Required Response Date: \\
N/A
\end{tabular}

\begin{tabular}{|c|c|c|c|c|c|c|c|c|}
\hline 15. & & DATA & TRANSMI TTED & & (F) & (G) & (H) & (1) \\
\hline $\begin{array}{l}\text { (A) } \\
\text { Item } \\
\text { No. }\end{array}$ & (B) Document/Drawing No. & $\begin{array}{l}\text { (C) } \\
\text { Sheet } \\
\text { No. }\end{array}$ & $\begin{array}{l}\text { (D) } \\
\text { Rev. } \\
\text { No. }\end{array}$ & $\begin{array}{l}\text { (E) Title or Description of Data } \\
\text { Transmitted }\end{array}$ & $\begin{array}{c}\text { Approval } \\
\text { Desig- } \\
\text { nator }\end{array}$ & $\begin{array}{l}\text { Roason } \\
\text { for } \\
\text { Trans- } \\
\text { mittal }\end{array}$ & $\begin{array}{l}\text { Origi- } \\
\text { nator } \\
\text { Dispo- } \\
\text { sition }\end{array}$ & $\begin{array}{l}\text { Receiv- } \\
\text { er } \\
\text { Dispo- } \\
\text { sition }\end{array}$ \\
\hline 1 & HNF-SD-HTI-ES-004 & & 0 & $\begin{array}{l}\text { Stabilization of In-Tank } \\
\text { Residual and External-Tank } \\
\text { Soil Contamination: FY } 1997 \\
\text { Interim Report }\end{array}$ & N/A & 3 & & \\
\hline & & & & ( & & & & \\
\hline & & & & & & & & \\
\hline & & & & & & & & \\
\hline & & & & & & & & \\
\hline & & & & & & & & \\
\hline
\end{tabular}

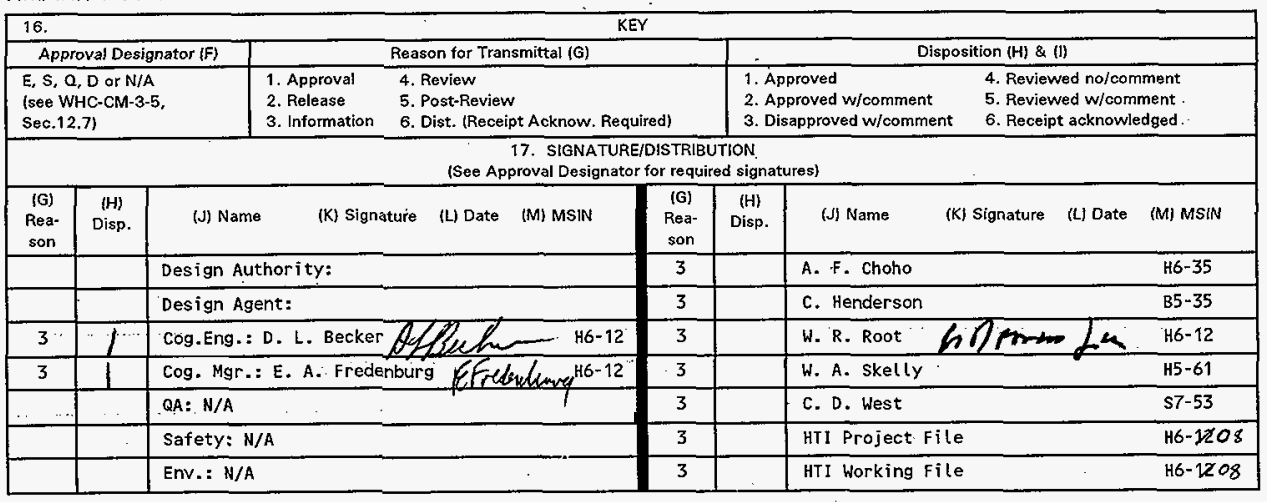

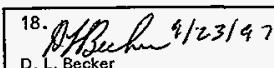

Signature of EDT

Originator

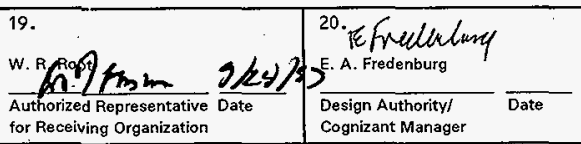

21. DOE APPROVAL (if required) Ctrl. No.

[] Approved

[] Approved w/comments

[] Disapproved w/comments 


\title{
Stabilization of In-Tank Residuals and External- Tank Soil Contamination: FY 1997 Interim Report
}

\author{
D. L. Becker \\ Numatec Hanford Corporation, Richland, Washington 99352 \\ U.S. Department of Energy Contract DE-AC06-96RL13200
}
EDT/ECN: 621741
Org Code: $8 \mathrm{C} 452$
UC: $U C-510$
B\&R Code: EW3130010
Charge Code: D26LI
Total Pages: 22

Key Words: Tank Stabilization, Residual Waste, Remediation, Soil Contamination

Abstract: This interim report evaluates various ways to stabilize decommissioned waste tanks and contaminated soils at the AX Tank Farm as part of a preliminary evaluation of end-state options for the Hanford tanks. Five technical areas were considered: (1) emplacement of smart grouts and/or other materials, (2) injection of chemical "getters" into contaminated soils surrounding tanks (soil mixing). (3) emplacement of grout barriers under and around the tanks, (4) the use of engineered barriers over the tanks, and (5) the explicit recognition that natural attenuation processes do occur. Research topics are identified in support of "key areas of technical uncertainty" in each of the five technical areas. Detailed cost/benefit analyses of the recomended technologies are not provided. This evaluation was performed by Sandia National Laboratories, Albuquerque, New Mexico, during FY 1997 under funding provided by the Tanks Focus Area (EM-50).

Volclay is a registered trademark of American Colloid Company, Skokie, Illinois

Benseal is a registered trademark of NL Industries, Inc., Houston, Texas

TRADEMARK DISCLAIMER. Reference herein to any specific comercial product, process, or service by trade name, trademark, manufacturer, or otherwise, does not necessarily constitute or imply its endorsenent, recommendation, or favoring by the United States Government or any agency thereof or its contractors or subcontractors.

Printed in the United States of America. To obtain copies of this document, contact: Document Control Services, P.O. BOX 950, Mailstop H6-08, Richland WA 99352 , Fax (509) $376-4989$.
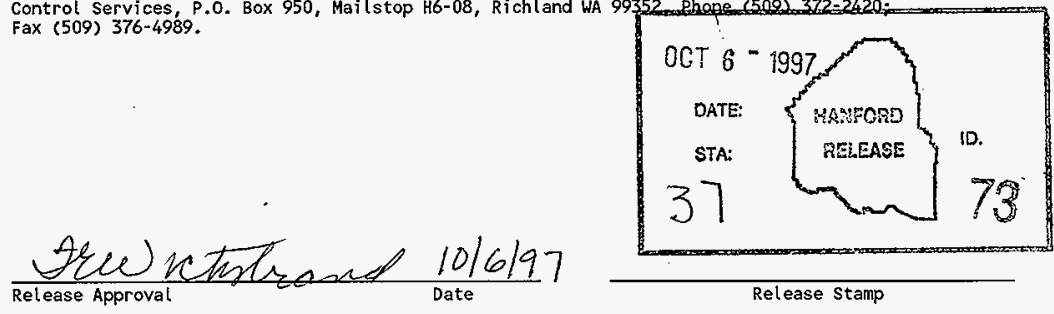


\section{Stabilization of In-Tank Residuals and External-Tank Soil Contamination: FY 1997 Interim Report}

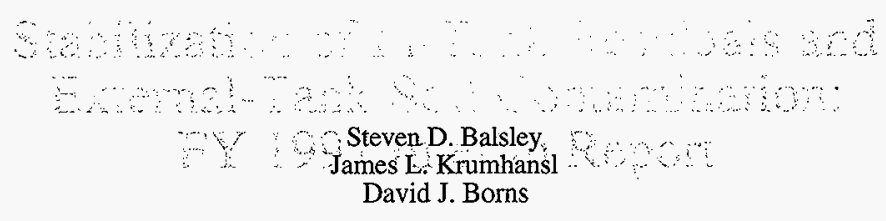




\section{INTRODUCTION}

The FY 1997 task plan called for evaluating various ways to stabilize decommissioned waste tanks and contaminated soils at the Hanford AX tank farm, as part of a preliminary evaluation of end-state options for the Hanford tanks. Five technical areas were considered: (1) emplacement of smart grouts and\%or other materials, (2) injection of chemical "getters" into contaminated soils surrounding tanks (soil mixing), (3) emplacement of grout barriers under and around the tanks, (4) the use of engineered barriers over the tanks, and (5) the explicit recognition that natural attenuation processes do occur.

Since March when funding arrived, we modified the scope of investigation in response to customer needs for $\mathrm{AX}$ tank farm evaluation. For example, the engineered barriers to be placed over the tanks are currently designed to be in compliance with RCRA mandates. We therefore believe this issue requires no further work. With respect to smart grouts (e.g., reducing grouts), we expand on the use of conventional grouts and how they might be modified to sequester specific radionuclides while also performing the traditional roles of filling spaces, reducing permeability, and cementing particles together. Specifically, we examined whether certain chemical "getters" might be compatible in the high-pH grout environment. A considerable amount of overlap among some of the topics was encountered. In particular, materials used to fill the tanks (e.g. grout-getter combinations) might also be mixed with the soil as a stabilizing agent, though the method and geometry of emplacement would be quite different. Several detailed tabulations of stabilization options for tanks and contaminated soils have been recently proposed (e.g., Kincaid et al., 1993; Treat et al., 1995) that we utilized in our selection of a specific design.

Finally, we emphasize that the expertise of the team assembled for this FY97 work is largely in geochemistry. Hydrologic and engineering related issues to be addressed in FY98 will be performed with support from other Sandia technical resources. A principal aica of uncertainty regarding waste stabilization concerns the chemical processes that occur as the various components 
of a disposal package interact. However, because an engineered design has not been finalized, we have started to address a number of significant hydrologic, economic and civil engineering issues with assistance from Sandia technical staff and contractors (Tom Burford, Brian Dwyer, Ernst Ahrens, Gordon McKeen), and a number of references (e.g., Kincaid et al., 1993; Rumer and Mitchell 1995; Treat et al., 1995). We also identify research topics in support of "key areas of technical uncertainty" in each of the five technical areas; research in these topics will be needed to demonstrate technical feasibility. Research topics that encompass hydrologic or engineering issues (i.e. non-geochemical topics) are noted in italics and can be considered in a FY98 program.

In this report we do not present a detailed cost/benefit analysis of the recommended technologies because the benefit to be realized by including a particular component is complex. For example, the technical impact of grouting may be perceived from both chemical and hydrologic perspectives, however the hydrologic issues are beyond the scope of the FY97 workplan, though they can be addressed in FY 98. In the 6/24/97 meeting it was agreed that a full treatment of such issues was not expected in the final report for FY 1997. Rather, our primary task is to assess chemical issues associated with reductions in solubility that might arise from interaction of the various components.

\section{EMPLACEMENTS WITHIN TANKS}

\subsection{Filler, Design}

A review of the substantial literature on tank closure revealed that mechanical stabilization is best achieved by backfilling tanks with an inexpensive coherent filler material. Suggested materials range from crushed and sieved basalt to grouts (Smyth et al., 1992). However, as long as tank integrity is maintained there is the possibility that water will collect and create a reservoir of fluid in contact with residual waste. Minimization of filler pore space and reducing pore diameter to the point where capilary forces will hold the fluid in place would minimize fluid-waste contact. In addition, the use of multiple sealant layers above the waste would reduce the possibility for 
formation of a single crack from top to bottom of the tank.

Tank filling strategies range from emplacement of granular materials to pumping of a semifluid material. Granular material emplacement necessitates (1) the regular distribution of material into the tank, and (2) compaction of the material to its "final" density in the time allotted for the closure process (Smyth et al., 1992). The engineering challenges of achieving these two goals are considerable. Rather, we prefer injection of semi-fluid materials that would flow over the irregular surfaces in each tank. Two cementitous grouts are identified with the requisite longevity and low cost; Portland cement based and bentonite based. Several commercially available bentonites may be emplaced as fluids and induced to seal, such as Volclay ${ }^{\circledR}$ and Benseal@. These are common components of subsurface barriers and the emplacement technologies are well established (Rumer and Mitchell, 1995). Costs are on the order of $\$ 125$ per ton of material. Wakeley and Ernzen (1992) developed a Portland cement-based grout with the appropriate rheological and thermal properties for "mass emplacement." Components of the grout are those typical of most Portland cements so the cost of the materials will be similar to those of normal concrete. Because the material is designed to fill vaults, emplacement costs are not excessive. This material should serve as a starting point for additional developments in the field (e.g., incorporation of fiber reinforcement that would inhibit crack propagation). A variety of fibrous materials (steel, glass, cellulose etc.) have been evaluated (Kosmatka and Panarese, 1990) and additional research should examine novel materials such as graphite fiber, which might have a longer lifetime in the tank environment.

We propose a layered, cementitous grout backfill structure rather than filling the tank with a single massive grout formulation (figure 1). Successful placement of multiple 16 inch layers of grout (dark lines in the blue field in figure 1) under simulated Hanford Grout Vault Program conditions has been demonstrated (Wakeley and Emzen, 1992). We also recommend a similar lift pouring strategy with sufficient intervening time to allow for the heat liberated in setting to 
dissipate. A 2 foot thick Benseal@ layer about 8 feet from the top of the stack is also recommended to help seal the underlying grout layers and to inhibit the formation of long, throughtank cracks. Consideration was given to placing bentonite layers further down as well, but it is not clear that the bentonite would support a greater thickness of grout, particularly if the tank walls were to fail and some of the clay was extruded into the surrounding formation.

\subsection{Filler, Function}

The function of this package is hydrologic and is intended to divert water away around the tank and preclude undue wetting of the waste (Kincaid et al., 1993) (Section 5.2). The propagation of cracks through the grout layers as a result of settling, seismic disturbances, etc. would encounter the plastic Benseal (8) or Volclay (B) layer and be arrested. Conversely, any contraction of the Benseal ${ }^{\circledR}$ or Volclay $(B$ layer would create a limited zone of porosity before encountering a rigid grout member. The hydraulic conductivity of a "tight" grout or concrete is typically at least three orders of magnitude less than soil, and the pore diameters in grout are also significantly less than that of the poorly sorted gravel fill surrounding the tanks (Brendel, 1997). Once this coarse material becomes dampened, its hydraulic conductivity will increase (Wierenga, 1995) and it will become the preferred path for draining the top of the tank. Thus, if a sustained recharge managed to pass through the RCRA cap, the gross effect of the proposed design would be to divert the flow around the tank and the waste inside.

\subsection{Filler, Research}

1. Better definition of the Portland cement and bentonite based grouts to actually be used (engineering design issue).

2. Structural engineering of the tank filling: The design inherently incorporates strong (brittle) and weak (plastic) layers that in aggregate will exert a significant pressure on the bottom and sides of the tank. The design should be one that is inherently stable and able to support its own 
HNF-SD-HTI-ES-004, Rev. 0

weight (engineering design issue).

3. Chemical stability of the bentonite-Portland cement interface: Bentonite seals are typically emplaced with the clay in the Na-exchanged form since it readily disperses in the emplacement water. The bentonite seal will, however, be in contact with the Portland cement based materiais on both sides. Bentonite clays used in grouts typically are converted to the CSH and CAH phases indigenous to Portland cements (Rumer and Mitchell, 1995). Even if this does not happen there will be at least some displacement of $\mathrm{Na}$ by $\mathrm{Ca}$ on the clay exchange sites. This increases the clay permeability significantly and causes the plasticity to drop dramatically (Grimm, 1968). In a marl, the effect of concrete on pore water chemistry is calculated to extend out about 0.2 meters in 12,500 years (Eikenberg and Lichtner, 1992), which suggests that if an unreacted septum of clay is to exist in the interior, the barrier should be on the order of $60 \mathrm{~cm}$ thick. Clearly, the process needs to be quantified (e.g., Lee et al., 1995) for the conditions relevant to the planned structure.

4. Continued evaluation of concrete longevity; apply models to site-specific circumstances and catalogue studies on the longevity of buried concrete structures. We note that the short service life of concrete in many PA documents pertains to the near-surface environment in which freeze-thaw and wet-dry cycles significantly enhance degradation rates. In the subsurface environment these effects are absent and we expect to show that significantly longer service lives are appropriate.

\subsection{Waste horizon treatment, design}

-The state of the residual waste is also a concern. Current strategies for pre-closure treatment of the tanks call for repeated sluicing to remove in excess of $90 \%$ of the contents. A significant fraction of the residuum is expected to be a watery fluid. The remainder will consist of discarded equipment and a pasty to semi-cemented mass of hydrous iron and aluminum hydroxide 
"sludge" adhering to the interior surfaces of the tank. Radionuclides sorbed on the solid fraction of the sludge will leach with difficulty. However, radionuclides in the sludge pore fluids and the watery fluid overlying the sludge will be highly mobile. The most abundant long-lived radionuclides of concern are: $\mathrm{Tc}, \mathrm{U}, \mathrm{Pu}, \mathrm{Np}$ and $\mathrm{Am}$.

A two-part strategy is proposed for treating the residual waste (figure 1). Initially, dry Portland cement (or other low-cost additives such as fly ash and lime). will be added to desiccate the waste. The next layer consists of crushed and sieved basalt with enough pore space to accommodate any of the pasty sludge that is displaced upward by the weight of the grout/bentonite cap. If only a few inches of sludge exists, the crushed stone can be omitted because the desiccant will likely wick the upper few inches of sludge dry and consume the overlying fluid. In either case, the waste heel will be quite porous so little hydrologic benefit can be ascribed to this treatment.

The goal of treating the waste using chemical means is to reduce radionuclide concentrations in solution. This can be accomplished with getters added to the waste prior to the desiccation step. For optimal getter performance, it may be desirable to neutralize the fluid with an acidic solution or by filling the headspace of the tank with an acidic gas, such as carbon dioxide. Getters work by either ion exchange or precipitating a phase containing the radionuclide of concern. A summary of potential getters is presented in Table 1. Except for the CST material, the cost of these getters is so small that the expense of the emplacement process will dominate the cost of placing the barrier.

Ramsower (1997) summarizes the likely radionuclide concentrations in the retrieval scenarios for the four AX farm tanks. Tank AX-102 fluids have the highest radionuclide concentrations, whereas concentrations in the remaining three tanks may be four orders of magnitude lower. In contrast to the mass balance estimates used to derive the values in Table 2, $\mathrm{AX}-102$ supernate analyses were reported for $\mathrm{Am}$ and $\mathrm{Pu}$ of $1.2 \times 10^{-5}$ moles/liter and $0.5 \times 10^{-5}$ 
moles/liter, respectively (Ramsower, 1997; see table 2-4 therein). Dissolved concentrations of Am are in reasonable agreement with Table 2 , whereas the $\mathrm{Pu}$ value is $\sim 13 \mathrm{x}$ lower. Am is apparently soluble in the tank fluids, but much of the $\mathrm{Pu}$ (and probably $\mathrm{U}$ and $\mathrm{Np}$ as well) may be associated with the solids in the sludge.

\subsection{Waste Horizon Treatment, Function}

Although we have not fully evaluated the function of each getter, the literature contains considerable information to make the following forecasts:

1. Magnetite $\mathrm{Fe}_{3} \mathrm{O}_{4}$ has been shown to lower Tc concentrations from an initial value of $10^{-6}$ molar

Table 1 .

Potential Getter Materials For Various Radionuclides

\begin{tabular}{|c|c|c|}
\hline Radionuclide & Getter Material & Cost \\
\hline $\mathrm{Cs}$ & $\begin{array}{l}\text { Crystalline Silicotitantate Titanate (CST) } \\
\text { Illitic Clays }\end{array}$ & $\begin{array}{l}\text { Expensive } \\
\text { Inexpensive }\end{array}$ \\
\hline $\mathrm{Sr}$ & $\begin{array}{l}\mathrm{CST} \\
\mathrm{SrCO}_{3}\end{array}$ & $\begin{array}{l}\text { Expensive } \\
\text { Inexpensive }\end{array}$ \\
\hline Am & $\begin{array}{l}\text { Hydroxycarbonate - coprecipitated with } \mathrm{Nd} \\
\text { Hydroxyapatite }\end{array}$ & $\begin{array}{l}\text { Inexpensive } \\
\text { Inexpensive }\end{array}$ \\
\hline TC & $\begin{array}{l}\text { Magnetite or other reducing agent } \\
\text { (may require nearly neutral solution to work quickly) }\end{array}$ & Inexpensive \\
\hline $\mathrm{Np}, \mathrm{Pu}$ & $\begin{array}{l}\text { Hydroxyapatite } \\
\text { Ca-phosphate coprecipitation } \\
\text { FeOOH }\end{array}$ & $\begin{array}{l}\text { Inexpensive } \\
\text { Inexpensive } \\
\text { Inexpensive }\end{array}$ \\
\hline $\mathrm{U}$ & $\begin{array}{l}\text { Magnetite or other reducing agent } \\
\text { Ca-phosphate coprecipitation } \\
\text { Ca-uraninates/cement phases }\end{array}$ & $\begin{array}{l}\text { Inexpensive } \\
\text { Inexpensive } \\
\text { Inexpensive }\end{array}$ \\
\hline $\mathrm{Se}$ & $\begin{array}{l}\mathrm{FeOOH} \\
\text { Fe-Hydrotalcite } \\
\text { (both may require nearly neutral solution to form) }\end{array}$ & $\begin{array}{l}\text { Inexpensive } \\
\text { Inexpensive }\end{array}$ \\
\hline I & $\begin{array}{l}\text { Cu oxides and sulfides } \\
\mathrm{Ag} \text { compounds }\end{array}$ & $\begin{array}{l}\text { Inexpensive } \\
\text { Inexpensive }\end{array}$ \\
\hline
\end{tabular}


Table 2.

Radionuclide Concentrations in Tank AX-102 Rinse Solutions

\begin{tabular}{|c|c|}
\hline Radionuclide & Concentration (mol/L) \\
\hline \hline Tc & $9 \times 10^{-6}$ \\
U & $6 \times 10^{-3}$ \\
Pu & $7 \times 10^{-6}$ \\
Am & $4 \times 10^{-6}$ \\
Np & $3 \times 10^{-6}$ \\
\hline
\end{tabular}

to a final value of $10^{-7}$ molar (Chu and Eriksen, 1996). However, the reaction is very slow in strongly basic solutions, and the solubility of the $\mathrm{TcO}_{2}$ increases above a pH of 9.2 due to the formation of the $\mathrm{TcO}(\mathrm{OH})_{3} \mathrm{CO}_{3}^{-}$complex. At $\mathrm{pH} \sim 12$ solubility reaches a value of $10^{-4}$ molar (Eriksen et al., 1992) thus, it may be necessary to temporarily neutralize the residual waste to accommodate $\mathrm{Tc}$ removal. Re-release of $\mathrm{Tc}$ is very slow; once it is sequestered by magnetite Tc should not go back into solution following grout emplacement. At present we cannot provide estimates of the quantity of magnetite required to scavenge a given amount of Tc. Further research on Tc sorption/precipitation on magnetite surfaces is needed.

2. A multitude of phases exist that might sequester $U$. The following discussion focuses on the use of cementitious materials to fix the more mobile U(VI) species. It is generally agreed that U(IV) solubility is exceedingly small. Theoretically, solubilities for U(VI) in a cementitious matrix range from $10^{-4}$ to $10^{-14}$ molar (Berner, 1990). However, in practice the measured value ranges from $10^{-7}$ to $10^{-8}$ molar (Atkins and Glasser ,1990; Moroni and Glasser, 1995), which is significantly lower than the value in Table 2 .

3. $\mathrm{Pu}$ is problematic because, like uranium, it exhibits a variety of valence states. Further, like uranium the tetravalent state is highly insoluble. The fact that AX tank fiuids contain about $10^{-5}$ moles/liter dissolved $\mathrm{Pu}$ indicates that an appreciable fraction exists in the hexavalent state. 
Therefore Pu behavior should resemble that of uranium, and its solubility should undergo a 10 to 100 fold decrease in a cementitious matrix. Secondly, it has been found that hydroxyapatite has a $\mathrm{Kd}$ for $\mathrm{Pu}$ of about 980 in saturated $\mathrm{NaCl}$ brines. When a getter acts by sorbing a radionuclide (rather than precipitating it) the final concentration depends strongly on the amount of getter that is added. Therefore a variety of design issues need to be resolved before an estimation can be made of the decrease in Pu concentration that might result from adding a hydroxyapatite getter.

4. Am presents an interpretational problem. On one hand, the hydroxy-carbonates of trivalent ions are exceedingly insoluble (Felmy et al., 1990; Carroll, 1993). Given the high concentrations of hydroxide and carbonate in these fluids, the solubility of Am should be less than $10^{-9} \mathrm{M}$. Yet, supernate Am concentrations on the order of $10^{-5} \mathrm{M}$ indicates that there may be other carbonate complexes that have yet to be evaluated. Fortunately, hydroxyapatite appears to have a very high $\mathrm{Kd}$ for $\mathrm{Am}$, in excess of 50,000. Again, issues of capacity exist as does the possibility that some Am complex will exist that is unique to these fluids.

5. Like Am, it appears that hydroxyapatite has a very high $\mathrm{Kd}$ (greater than 59,000) for $\mathrm{Np}$. Furthermore, fluids rich in $\mathrm{Na}^{+}$and $\mathrm{CO}_{3}{ }^{2-}$ will exist in the waste so the solubility of $\mathrm{Np}$ will be limited by $\mathrm{NaNpO}_{2}\left(\mathrm{CO}_{3}\right)_{2}$ to values in the range $1-5 \times 10^{-4} \mathrm{M}$ (Rund et al., 1996). This may permit use of a solubility limit in the $10^{-4} \mathrm{M} \mathrm{Np}$ range for PA diffusive transport calculations.

\subsection{Waste Horizon Treatment, Research}

1. Explore the systematics of Tc sorption on magnetite in the relevant solutions. This will be an experimental study where typical DSSF-type tank fluids will be diluted, neutralized to varying degrees with $\mathrm{CO}_{2}$, and then spiked with Tc. Different forms of magnetite and other $\mathrm{Fe}^{+3} / \mathrm{Fe}^{+2}$ solid preparations will also be added. For those getters that successfully remove Tc, the desorption kinetics will be determined at pH values likely to exist in cement pore fluids (a pH 
of about 12).

2. Using $\mathrm{U}$ and $\mathrm{Nd}$ as a stand-in for Am to experimentally evaluate the systematics of sorption on hydroxyapatite in DSSF-type solutions is proposed (see \#1 above). The effectiveness of preformed hydroxyapatite in removing these elements will be compared with that of precipitating fresh calcium phosphate in solutions that are pre-spiked with $\mathrm{Nd}(\mathrm{Am})$ and $U$.

3. Resolve the issue of why the Am(Nd) appears to remain in solution when the calculated solubility appears to be so low. This will be a combined computational and experimental study. Two computer codes based on thermodynamic equilibrium are available (REACT and $\mathrm{EQ} 3 / 6)$ and will be applied to the problem.

4. Do a mock-up of the sludge desiccation process with emphasis on characterizing both the chemical and textural features that result, as well as determining the thickness of an artificial sludge heel that can be desiccated.

5. Search the literature and incorporate what the saitcrete programs have learned about the stability and leach characteristics of their waste form.

6. Provide REACT and EQ3/6 computations to demonstrate that tetravalent $U$ and Pu concentrations should remain much less than $10^{-8}$ molar over the relevant range of conditions. If possible, do the same for Nd (e.g. Am).

\section{Grout Barriers Under and ARound the TANK}

\subsection{Design}

Rumer and Mitchell (1995) have edited a definitive work on the construction of subsurface barriers that contains far more information than can summarized here. However some pertinent information such as general costs and dimensions that can be achieved with existing technologies are listed in Table 3. Only inorganic materials were considered for this application because organic 
"chemical grouts" cannot be demonstrated to have lifetimes commensurate with the required regulatory time frame.

The third part of our design is a skirt to be emplaced against the exterior walls of the tank (figure 1). Because it is desirable to minimize the amount of soil brought to the surface, and because a close bond to the curved outside tank surface is needed, jet grouting is the preferred technology. The skirt would extend some distance beyond the base of the tank, and would have a wall thickness of about a meter. A 3-foot thick skirt that was 50 feet high would contain about $1000 \mathrm{~m}^{3}$ of grout and cost about $\$ 24 \mathrm{~K}$ (Dwyer, 1994).

Table 3.

Representative Costs of Different Types of Barriers

\begin{tabular}{|l|c|c|c|c|}
\hline \multicolumn{1}{|c|}{ Wall Type } & Width (ft) & Depth (ft) & $\begin{array}{c}\text { Unit Cost } \\
\left(\$ / \mathbf{f t}^{2}\right)\end{array}$ & $\begin{array}{c}\text { Production Rate } \\
\left(\mathrm{ft}^{2} / \mathbf{1 0} \mathbf{h r s}\right)\end{array}$ \\
\hline \hline Soil Bentonite & $2-3$ & 80 & $2-8$ & $2500-15000$ \\
Cement Bentonite & $2-3$ & 80 & $5-18$ & $1000-8000$ \\
Biopolymer Drain & $2-3$ & 70 & $7-25$ & $1500-5000$ \\
Deep Mixing & 2.5 & 90 & $6-15$ & $1000-8000$ \\
D-mix, Structural & 2.5 & 90 & $15-30$ & $1000-3000$ \\
Jet Grouting & $1.5-3$ & 200 & $30-80$ & $200-2500$ \\
Grout Curtain & $0.5-1$ & 200 & $40-100$ & $200-1000$ \\
\hline
\end{tabular}

\subsection{Function}

The skirt performs two functions. By extending beyond the base of the tank it diverts the flow of ground water past the base of the tank. Thus, the only remaining mechanism for getting the waste out of the decommissioned tank is diffusion, which is exceedingly slow when the concentration gradient through unsaturated soil is small (the generic function of the getters) and distances of tens of feet are involved.

Secondly, increasing the wall thickness to about a meter would preclude degradation of the wall to the point that radionuclides could exit laterally, or that horizontally moving ground water 
would enter the tank. Wall thickness determination was based on concrete ionic diffusion coefficients on the order of $10^{-8} \mathrm{~cm}^{2} / \mathrm{sec}$ (Wanton et al., 1990). A plane source with a zero concentration at the boundary will have a depletion front due to diffusion that moves only about 0.5 meter into the mass over 10,000 years. Although there are many refinements on the calculations (e.g., Haworth et al., 1988; Alcorn et al., 1990; Wanton et al., 1990; Lin, 1991; Adenot and Buil, 1992; Buil et al., 1992; Pihlajavaara, 1992) diffusion will control the deterioration rate of concrete, and in the $10^{4}$ year period of concern; maximum $\sim 0.5 \mathrm{~m}$ of degradation is expected under the most adverse circumstances.

Two points need to be made in regard to this design. First, to take credit for the design will require a specialized fluid flow model able to handle small geometric details. It is not something to be found as a part of the garden-variety PA package. Secondly, the skirt does not have to be a perfect barrier. A reasonable guess might be that the barrier will be $90 \%$ effective. This, however, means that the source term for whatever PA package is being used would be only be $10 \%$ of that which would exist had not the skirt been constructed. This can make a significant difference in the outcome of such a calculation.

\subsection{Research}

1. There is no chemical benefit to this component so the issues associated with its implementation are hydrologic. At least in its simplified form it should be possible to model the flow lines around such a geometry using in-house codes such as TOUGH. Issues such as the optimal extent of the skirt below the tank bottom and the minimum acceptable hydraulic conductivity of the grout and clay layers filling the tank should also be addressed. The impact of increasing rainfall could also be treated. The effect of hypothetical hair line cracks (either in the tank filling plug or between the wall of the tank and the skirt) on overall water flow pattems could also be addressed (e.g., Walton et al., 1990). 
2. Continue to evaluate new barrier technologies, such as are suggested in a just-received Russian report that is currently being evaluated at SNL.

\section{Chemical Injection to the Solls surRounding the tanks (SOIL MIXING)}

\subsection{Design}

Directional drilling is required to get beneath the tanks. The geometry typically proposed is a V-shaped pattern of holes that intersect beneath the tank. This is similar to the design proposed in section 4.3 .3 of Treat et al. (1995). Assuming the tank bottom to be at a depth of 55 feet (Kos, 1997) and using a $45^{\circ}$ inclined hole, a 190 foot long hole would be required to penetrate to the center of the AX tank farm "fourplex". The depth of the hole at this point would be 135 feet so this intersection would be above the water table. The entire area of the grout panels (including end caps) is about $1.12 \times 10^{5}$ square feet.

Such a barrier was constructed by jet grouting around a small 7,500 l tank at the Hanford Geotechnical Facility in 400 area at a cost of $\$ 24 / \mathrm{m}^{3}$ (Dwyer, 1997). Peterson and Landis (in Rumer and Mitchell, 1995, p. 185-209) discuss such structures in detail and are less encouraging regarding costs: "Jet Grouting. For conventional civil engineering applications, high pressure jet grouting typically costs $\$ 15$ to $\$ 20$ per square foot for columnar walls. For thin diaphragm walls using jet grouting, costs are estimated at $\$ 10$ to $\$ 15$ per square foot. For estimating purposes, it is assumed that the typical high pressure jet grouted wall has a diameter of roughly 6 feet and the thin diaphragm wall length is 5 feet in both directions. In addition, the cost of directional drilling is estimated at $\$ 8$ to $\$ 25$ per square foot for columnar walls drilled on 6-foot centers and $\$ 5$ to $\$ 15$ per square foot for thin diaphragm walls drilled on 10-ft centers. The installed cost of a jet grouted columnar floor is estimated at $\$ 23$ to $\$ 45$ per square foot and, for thin diaphragm wall floor, $\$ 15$ $\$ 30$ per square foot. Not included in these estimates are the costs of the grouting materials, waste disposal, and contingencies." In short, to construct this barrier around the fourplex AX tank farm 
will cost in excess of a million dollars.

A somewhat simpler application of jet grouting would be to treat the contaminated soils around the tanks. Brendel (1997) estimates that there are $1.63 \times 10^{4}$ cubic yards of material. The heterogeneous distribution of these soils would be difficult to treat with any other mass stabilization process. The process should involve vertical drilling of shallow holes and have an associated cost of approximately $\$ 24 / \mathrm{m}^{3}$; total cost would therefore approximate $\$ 300 \mathrm{~K}$.

\subsection{Function}

Typically the $V$-shaped troughs are intended to completely seal the tank off from its surroundings. With the addition of an organic inner liner, this is a tractable problem - at least for the short term (Williams and Ward, 1997). However, given the 10,000 y regulatory period, it is relevant to ask whether this is a desirable objective. A climate shift to a damper mode may cause the liner become ponded and induce prolonged leaching of the waste. It makes more sense to inject getters without a binder and create a permeable reactive barrier (Shoemaker, et al., in Rumer and Mitchell, 1995, p.301-353). As with the skirt, the effectiveness is proportional to the area actually covered. If the permeable reactive barrier were $90 \%$ effective at scavenging radionuclides exiting the tank, the source term would be reduced by another factor of ten. However, given the size of the engineering task, the difficulty of verifying a successful emplacement, and cost, it is likely that the rest of the PA should demonstrate a clear need for this structure before it is seriously proposed.

Jet grouting may be the only economic method of treating contaminated soils in place given their extremely irregular distribution. A combination of getters and grout would both reduce the flux of water that contacts the waste and reduce the solubility of the radionuclides in the small amount of water that does gain access to the waste. Essentially the same computational procedure used to predict flow and flow around the tanks might be used for jet grouted masses of soil, though the dimension would clearly be smaller. However, if the jet grouted masses of soil do not 
have an uncontaminated rim of grout it would be necessary to consider the diffusion of radionuclides out through the side of the mass in addition to the loss through the base.

\subsection{Research}

1. Getter research similar to that proposed for the in-tank stabilization plan discussed in section 2.6. Additional engineering-related issues concerning emplacement options and optimal groutgetter mixtures will also be addressed.

\section{THE EXPLICIT RECOGNITION OF NATURAL ATtENUATION}

\subsection{Design}

Natural attenuation is not an engineering issue - but rather a recognition of the natural interactions between waste (solutions, usually) and the soils traversed by the waste. The problem of barrier design for natural attenuation is partly one of how the PA package is developed and partly one of getting the appropriate data. Most PA packages employ a Kd approach to model radionuclide retardation so the first step is to get site specific parameters. Thus, one "design" for incorporating natural attenuation is to obtain the best $\mathrm{Kd}$ values available for the soils underlying the AX tank farm. Kincaid et al. (1993) provides a Kd tabulation AX farm soils, but values given for the actinides other than $U$ seem to be much less than might be expected (e.g., Brady and Kozak, 1995). Thus, one way of designing for natural attenuation will be to improve on the Kd values to be put into the PA calculations.

However, providing the "correct" site specific Kd values may not really address the issue of incorporating natural attenuation. This follows from the fact that the $\mathrm{Kd}$ approach often does not represent the chemical processes that govern the mobility of a particular radionuclide. This typically arises from one of two causes: (1) precipitation/dissolution mechanisms may dominate, and these simply have no analogue in the mathematics of the Kd approach, and (2) where ion exchange is actually the proper mechanism, the desorption step may be so slow that assuming 
reversible equilibrium greatly overestimates the amount of radionuclides available for leaching: Once the proper data is obtained the next step requires rewriting the PA code to account for this new and more complex chemistry. Reactive transport codes are just now making their appearance and would require a substantial effort to embody into the program. Finally, historical Kd approaches are based on normal rainfall assumptions. From the literature, we are aware of substantial surface leaks at the AX Tank Farm that were followed by extensive water flushing operations that probably lead to far broader initial depth dispersal of radionuclides (Ramsower, 1997; Appendix A, p.6). These releases will require special modeling assumptions to correctly interprete Kd's.

\subsection{Function}

The function of incorporating natural attenuation clearly lies in providing more realistic estimates of expected radionuclide migration rates. But, to achieve this first requires improving the PA package that makes the predictions.

\subsection{Research}

1. Compile a wider list of Hanford Site $\mathrm{Kd}$ values and use geochemical modeling codes such as REACT to interpret the data. In particular, try and determine where ion exchange is likely to have operated and where it is more likely that what limited the dissolved concentration of a radionuclide was the precipitation of a phase. This will at least tell us when we might be justified in using a $\mathrm{Kd}$ approach in modeling the migration of a radionuclide.

2. Obtain $\mathrm{AX}$ tank farm sediments and perform batch $\mathrm{Kd}$ and column transport experiments using various diluted and neutralized derivatives of the DSSF-type fluids. It is likely that the unique chemistry of the leaked tank fluids will effect $\mathrm{Kd}$ values. This is not something that will be in the literature, so it will have to be evaluated experimentally. Again, only a few of the relevant elements can be tested easily but this should give a good idea of how much of an effect this can 
have.

\section{REFERENCES}

Adenot, F. and Buil, M., 1992. Modeling of the corrosion of cement paste by deionized water. Cement Concrete Res. 22, 489-496.

Alcorn, S.R., Coons, W.E. and Gaminer, M.A., 1990. Estimation of longevity of Portland cement grout using chemical modeling techniques. Mat. Res. Soc. Symp. Proc. 176, 165 173.

Atkins, M. and Glasser, F.P., 1990. Encapsulation of radioiodine in cementitous waste forms. Mat. Res. Soc. Symp. Proc. 176, 15-21.

Berner, U., 1990. A thermodynamic description of the evolution of pore water chemistry and uranium speciation during degradation of cement, Paul Scherer Institut.

Brady, P.V. and Kozak, M.W., 1995. Geochemical engineering of low level radioactive waste in cementitous environments. Waste Management 15, 293-301.

Brendel, D.F., 1997. A summary of leaks and spills contributing to AX tank farm vadose zone contamination, SGN Eurosys Services Corp. SESC-97-134

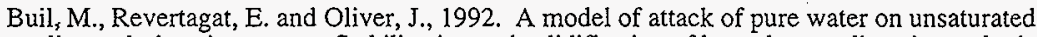
lime solutions in cement. Stabilization and solidification of hazardous, radioactive and mixed wastes. Vol.2. T. M. Gilliam and C. C. Wiles, ASTM Special Technical Publictions (STP) 1123: 227-241.

Carroll, M.A., 1993. Precipitation of Nd-Ca carbonate solid solutions at $25^{\circ} \mathrm{C}$. Geochim. Cosmochim. Acta 57, 3383-3393.

Chu, D. and Eriksen, T.E., 1996. Reduction of pertechnetate by heterogeneous electron transfer from Fe(II)-containing geologic material. Environ. Sci. Technol. 30, 2263-2269.

Dwyer, B.P., 1997. Demonstration of close-coupled barriers for subsurface containment of buried waste, Sandia National Laboratories. SAND97-1193

Eikenberg, J. and Lichtner, P.C., 1992. Propagation of hyperalkaline cement pore waters into the geologic barrier surrounding a radioactive waste repository. Rotterdam, Balkema.

Eriksen, T.E., Ndalamba, P., Bruno; J. and Caceci, M., 1992. The solubility of $\mathrm{TcO}_{2} \mathrm{nH}_{2} \mathrm{O}$ in neutral to alkaline solution under constant $\mathrm{pCO}_{2}$. Radiochim. Acta.

Felmy, A.R., Rai, D. and Fulton, R.W., 1990. The solubility of $\mathrm{AmOHCO}_{3}$ (c) and the aqueous thermodynamics of the system $\mathrm{Na}^{+}-\mathrm{Am}^{3+}-\mathrm{HCO}_{3}{ }^{-}-\mathrm{OH}^{-}-\mathrm{H}_{2} \mathrm{O}$. Radiochim. Acta 50, 193-204.

Grimm, R.E. 1968. Clay mineralogy. New York, McGraw-Hill.

Haworth, A., Sharland, S.M. and Tweed, C.J., 1988. Modeling of the degradation of cement in a 
HNF-SD-HTI-ES-004, Rev, 0

nuclear waste repository. Mat. Res. Soc. Symp.

Kincaid, C.T. and others, 1993. Performance assessment of grouted double-shell tank waste disposal at Hanford, Westinghouse Hanford Co. WHC-SD-WM-EE-004, Rev. 0

Kos, S.E., 1997. Vadose zone characterization project at the Hanford tank farms- AX tank farm report. GJO-97-7-TAR

Kosmatka, S.H. and Panarese, W.C., 1990. Design and control of concrete mixtures- 13th edition. Skokie, $\mathrm{L}$, Portland Cement Assoc.

Lee, J.H., Roy, D.H., Mann, B. and Stahl, D., 1995. Integrated approach to modeling long-term durability of concrete engineered barriers in LLRW disposal facilities. Mat. Res. Soc. Symp. Proc. 353, 881-889.

Lin, S.K., 1991. Chloride diffusion in a porous cylindrical concrete column. Chem. Eng. Sci. 46, 1189-1192.

Moroni, L.P. and Glasser, F.P., 1995. Reactions between cement components and U(VI) oxide. Waste Manag. 15, 243-254.

Pihlajavaara, S.E., 1992. Estimation of the service life of concrete under different conditions with special reference to radioactive waste repositories. Nucl. Engineer. Design 138, 127-133.

Ramsower, D.C., 1997. AX tank farm waste inventory study for the Hanford Tanks Initiative (HTI) Project, Eurysis Services Corp. EN-RPT-02

Rumer, R.R. and Mitchell, J.K., 1995. Assessment of barrier containment technologies: a comprehensive treatment for environmental remediation applications. International Containment Technology Workshop. Aug. 29-31, Baltimore, Maryland.

Runde, W., Neu, M.P. and Clark, D.L., 1996. Neptunium (V) hydrolysis and carbonate complexation: experimental and predicted neptunyl solubility in concentrated $\mathrm{NaCl}$ using the Pitzer approach. Geochim. Cosmochim. Acta 60, 2065-2073.

Smyth, J.D., Shade, J.W. and Somasundaram, S., 1992. Assessment of dome-fill technology and potential fill materials for the Hanford single-shell tanks, Pacific Northwest National Laboratory. PNL-8014

Treat, R.L. and others, 1995. Feasibility study of tank leakage mitigation using subsurface barriers, Westinghouse Hanford Company. WHC-SD-WM-ES-300 Rev. 1

Wakeley, L.D. and Ernzen, J.J., 1992. Grout for closure of the demonstration vault at the U.S.DOE Hanford facility, Dept. of Army, Waterways Experiment Station, Vicksburg, MS.

Walton, J.C., Plansky, S.E. and Smith, R.W., 1990. Models for estimation of service life of concrete barriers in low-level radioactive waste disposal. NUREG/CR-5542, NRCWashington, D.C. 
Wierenga, P.J., 1995. Water and solute transport and storage. Handbook of vadose zone characterization and monitoring. L. G. Wilson, L. G. Everett and S. J. Cullen: 41-60.

Williams, C.V. and Ward, D.W., 1997. Verification of the integrity of barriers using gas diffusion, Sandia National Laboratories, SAND97-1425. 


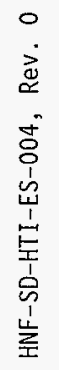

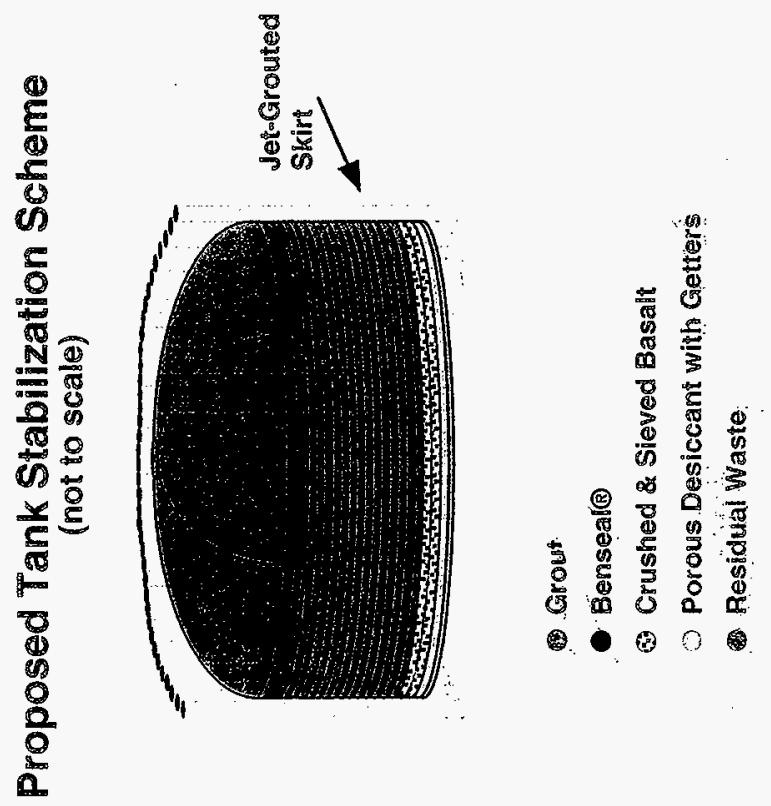

